\title{
Ganged Up On: How the US immigration system penalises and fails to protect Central American minors who are trafficked for criminal activity by gangs
}

Katherine Soltis and Madeline Taylor Diaz.

\section{Abstract}

This article addresses the failures of the United States immigration system to protect Central American minors who were trafficked for exploitation in criminal activities by gangs. In particular, it focuses on the ways in which the US immigration system denies humanitarian protection to Central American minors who were forced to participate in criminal activity by the Mara Salvatrucha (MS-13) and $18^{\text {th }}$ Street gangs, and instead detains them. The article will examine this trend in the context of a larger proclivity to criminalise immigration in the US, particularly minors fleeing violence in Central America. We draw upon our experience representing Central American minors in their applications for humanitarian immigration relief to highlight how the US immigration system fails to protect this vulnerable population and penalises these children for their own victimisation.

Keywords: asylum seekers, human trafficking, minors, gangs, immigration

Please cite this article as: K Soltis and M Taylor Diaz, 'Ganged Up On: How the US immigration system penalises and fails to protect Central American minors who are trafficked for criminal activity by gangs', Anti-Trafficking Review, issue 16, 2021, pp. 104-122, https://doi.org/10.14197/atr.201221167.

This is an open-access article distributed under the terms of the Creative Commons Attribution License (CC-BY). Under the CC-BY license, the public is free to share, adapt, and make commercial use of the work. Users must always give proper attribution to the authors and the Anti-Trafficking Review. 


\section{Introduction}

Samuel ${ }^{1}$ grew up in a district of El Salvador controlled by the Mara Salvatrucha (commonly known as MS-13) gang. MS-13 marked the walls in town with graffiti-both to let the residents know of its control and as a warning to rival gang members. When Samuel was 8 years old, a gang member told him to stand watch as they robbed a local business and alert them if he saw a police officer. Samuel, unaware of the implications of the request and out of fear of retribution, did so.

The requests from MS-13 started small: to act as a lookout, to transport messages, or to buy the gang alcohol or food. Over time, threats began to accompany the demands. Gang members demanded Samuel carry drugs for them and threatened to harm him or his family if he refused. Samuel felt he had no choice but to oblige. When the gang demanded that Samuel, who was then 12 years old, go with them to fight rival gang members, he refused. As a punishment, they murdered Samuel's cousin in front of him and told him that his other family members would be next if he refused their demands again. Later, when Samuel refused to act as a lookout while the MS-13 murdered a rival gang member, he was forced to watch as the gang beheaded his friend.

Fearing for his life, Samuel fled to the United States (US) at the age of 14. However, he and thousands of Central American children like him seeking refuge in the US are frequently barred from humanitarian immigration relief and detained because of the criminal conduct they were forced to engage in by gangs. ${ }^{2}$

Despite the US's obligations under the Trafficking Victims Protection Act (TVPA) and the US government's professed dedication to protecting human trafficking victims, children like Samuel are often excluded from immigration protections. The TVPA and international instruments include provisions that state that victims of trafficking should not be punished for crimes they were forced to

\footnotetext{
All names used in the paper have been changed to protect confidential information.

2 D Uchimaya, 'Falling Through the Cracks: Gang Victims as casualties in current asylum jurisprudence', Berkeley La Raza Law Journal, vol. 23, 2013, pp. 109-162, p. 144, http://dspace.creighton.edu:8080/xmlui/bitstream/handle/10504/127404/ Uchimiya_23BerkeleyLaRazaLJ109.pdf; JM Chacón, 'Whose Community Shield?: Examining the removal of the "criminal street gang member", University of Chicago Legal Forum, vol. 2007, 2007, pp. 317-358, https://chicagounbound.uchicago.edu/cgi/ viewcontent.cgi? article $=1412 \&$ context $=$ uclf.
} 
commit. ${ }^{3}$ However, the Immigration and Nationality Act (INA), the primary law governing immigration in the US, carries extreme consequences for applicants with a criminal history without regard for whether the criminal activity was the result of force or coercion. Apart from one waiver in the INA available for criminal conduct incident to trafficking - which, as discussed below, is very limited in its reach-the INA does not contain a duress defence or other exceptions for trafficking victims. Notably for children trafficked for exploitation in criminal activities, norms regarding mental capacity and legal culpability are largely absent from the INA and case law, leading to harsh and disproportionate consequences for these minors.

This article explores the draconian effects of US immigration policies on Central American minors who, like Samuel, were trafficked for criminal activity by gangs in their countries of origin. In the sections below, we begin by providing an overview of the extreme violence perpetrated by gangs in Central America as well as the gangs' practice of coercing minors into servitude. Drawing from our experience as immigration attorneys representing approximately 500 Central American minors since 2013, we will demonstrate how our immigration system routinely denies protections to Central American minors trafficked for exploitation in criminal activities and subjects them to prolonged detention. In particular, we will focus on criminal-related inadmissibility grounds, bars to asylum, and detention as these are areas in which our clients frequently face barriers to protection. Although this paper is not based on a systematic review of our cases nor is it an empirical research project, we hope that our professional observations and clients' stories will shed light on the need for expanded protections for minor trafficking victims in US immigration law.

\section{Trafficking in Minors by Central American Gangs: The issue of coercion}

Like Samuel, hundreds of thousands of Central Americans flee from their home countries to the US every year ${ }^{4}$ to seek protection from pervasive gang violence by the rivalling MS-13 and the $18^{\text {th }}$ Street gangs. The $18^{\text {th }}$ Street gang

3 See, e.g., 22 U.S.C. $\$ 7101$ (b)(19) (TVPA); Council of Europe Convention on Action against Trafficking in Human Beings, Warsaw, 2005, Article 26; Office of the High Commissioner for Human Rights, Recommended Principles and Guidelines on Human Rights and Human Trafficking, OHCHR, Geneva, 2002, Recommended Principle 7.

4 US Customs and Border Protection, 'U.S. Border Patrol Nationwide Apprehensions by Citizenship and Sector (FY2007 - FY 2019)', January 2020, retrieved 30 May 2020, https://www.cbp.gov/sites/default/files/assets/documents/2020-Jan/ U.S. $\% 20$ Border $\% 20$ Patrol $\% 20$ Nationwide $\% 20$ Apprehensions $\% 20$ by $\% 20$ Citizenship $\% 20$ and $\% 20$ Sector $\% 20 \% 28 F Y 2007 \% 20-\% 20$ FY\%202019\%29_1.pdf. 
originated in the 1960s in Los Angeles, California among Mexican youths, and the MS-13 gang originated in the 1980s, also in Los Angeles. ${ }^{5}$ These gangs were formed largely as a response to existing gang violence, racial tensions, and prejudice against Latinx immigrants in the United States. The prevalence of gangs in Central America grew as immigrants from the United States were deported, largely as a result of a 1996 law known as the Illegal Immigrant Reform and Immigrant Responsibility Act (IIRAIRA). This led to the 'exportation' of gang culture to Central America.

Deportees from the US brought the gangs with them, and they quickly amassed power by exploiting civil unrest, weak institutions, and poverty in post-conflict and Civil War societies. The Civil War in Guatemala from 1960 to 1996, the Civil War of El Salvador from 1979 to 1992, US military interventions and backing of coups, and US neoliberal policies played a central role in the poverty and instability in the region which created space for the emergence of violent gangs in Central America. ${ }^{6}$

The civil unrest caused by these gangs is enormous, such that:

Those who reside and work in seriously gang affected areas live in a state of persistent fear and hyper-vigilance and are subjected to oftentimes incomprehensible levels of psychological and physical violence. In these areas, gangs influence-or dictate directly-virtually every aspect of day-to-day life for the public at-large, and exert a perverse influence over governmental and non-governmental policies and practices. ${ }^{7}$

5 CR Seelke, Gangs in Central America, Congressional Research Service, 29 August 2016, retrieved 12 March 2021, https://fas.org/sgp/crs/row/RL34112.pdf.

6 E Zilberg, Space of Detention: The making of a transnational gang crisis between Los Angeles and San Salvador, Duke University Press, Durham, 2011; P Benson, EF Fischer, and K Thomas, 'Resocializing Suffering: Neoliberalism, accusation, and the sociopolitical context of Guatemala's new violence', Latin American Perspectives, vol. 35, issue 5, 2008, pp. 38-58, https://doi.org/10.1177/0094582X08321955; JM Cruz, 'The Root Causes of the Central American Crisis', Current History, vol. 114, issue 769, 2015, pp. 43-48, http://doi.org/10.1525/curh.2015.114.769.43.

7 T Boerman and A Golob, 'Gangs and Modern-Day Slavery in El Salvador, Honduras and Guatemala: A non-traditional model of human trafficking', Journal of Human Trafficking, 2020, p. 10, https://doi.org/10.1080/23322705.2020.1719343. 
Though the gangs have grown in size and strength since their inception, MS-13 and $18^{\text {th }}$ Street rely on the recruitment of young and often poor people. ${ }^{8}$ While gang violence is pervasive, the recruited membership of the gangs is primarily made up of poor and disenfranchised minors and young adults. Children, particularly poor children, are viewed as easy targets for recruitment and coercion by the gangs. 'They are employed in the gangs' main source of revenue: street-level drug sales and extortion of small local businesses. ${ }^{10}$ In contrast to the lower level roles played by children and youths, MS-13's recent strategy has involved 'infiltrating members into the police and military, and sending selected cadres to universities to become lawyers, accountants, and MBAs', who go on to hold influential and leadership positions within the gangs. ${ }^{11}$

Given the many societal factors contributing to minors' involvement with gangs, it is often difficult to determine whether a minor's participation was voluntary or the result of force and coercion such that the act would constitute trafficking under the TVPA. In contrast to the UN Trafficking Protocol's definition of trafficking in persons, which does not require force or coercion in cases involving children, the TVPA's definition of labour trafficking does not distinguish between adults and children and requires perpetrators use either force, fraud, or coercion. ${ }^{12}$ The TVPA defines labour trafficking as: 'the recruitment, harboring, transportation, provision, or obtaining of a person for labor or services, through the use of force, fraud, or coercion for the purpose of subjection to involuntary servitude, peonage, debt bondage, or slavery'. ${ }^{13}$ Coercion, in turn, is defined as 'threats of serious harm to or physical restraint against any person; any scheme, plan, or pattern intended to cause a person to believe that failure to perform an act would result in serious harm to or physical restraint against any person; or

8 Boerman and Golob, p. 10; D Farah and K Babineau, 'The Evolution of MS 13 in El Salvador and Honduras', Prism, vol. 7, no. 1, 2017, pp. 58-73. The media has used terms, often sensationalised, to highlight the demographics of the MS-13 and $18^{\text {th }}$ Street gangs as young and poor, referring to the gangs as 'mafias of the poor' and a 'children's army'. See International Crisis Group, Mafia of the Poor: Gang violence and extortion in Central America, International Crisis Group, 6 April 2017, retrieved 30 May 2020, https://www.crisisgroup.org/latin-america-caribbean/central-america/62-mafiapoor-gang-violence-and-extortion-central-america; R Connell and RJ Lopez, 'An Inside Look at 18th St.'s Menace', Los Angeles Times, 17 November 1996, https://www.latimes. com/archives/la-xpm-1996-11-17-mn-1539-story.html.

9 Boerman and Golob, p. 1.

10 Ibid., p. 10; Farah and Babineau.

11 Farah and Babineau, p. 60.

12 UN General Assembly, Protocol to Prevent, Suppress and Punish Trafficking in Persons, Especially Women and Children, Supplementing the United Nations Convention against Transnational Organized Crime, 15 November 2000, (Trafficking Protocol), Article 3(c).

1322 USC \ $7102(11)(B)$. 
the abuse or threatened abuse of the legal process. ${ }^{14}$

As with other types of trafficking, it is often difficult to draw a clear line between coercion and voluntariness in these cases, and instead of seeing these two positions as dichotomous, we might, rather, approach them as two extremes on a continuum. At one end of the spectrum, youths may voluntarily join a gang or perform labour for a gang. Gang membership confers benefits for youths, including 'camaraderie, power, protection, status, money, etc. ${ }^{15}$ and, given these benefits, may be a desired option.

Minors may also decide to join a gang due to more subtle forms of coercion. We acknowledge the numerous factors which might play into a child's acquiescence to demands by gang members, including poverty and the promise of pay, lack of employment opportunities, the need for protection and housing if they do not have other parental figures to care for them, and status among peers. Notably, under the US definition of trafficking, these cases would not involve coercion, although we recognise the coercive powers at play. Adding to the complexity in determining voluntariness is the fact that voluntariness may change over time. Minors who may have initially joined voluntarily face limited options should they decide they want to leave the gang. According to the lore of the gangs, there are only three ways out of their membership: prison, hospital, or death. ${ }^{16}$ As a result, minors may become victims of exploitation and coercion even though they initially joined voluntarily.

Cases at the other end of the spectrum involve acts of violence and threats to coerce minors into servitude to the gang. Cases like Samuel's, discussed in the introduction, involve threats of violence and death against the minor and his family to coerce his labour. In another case, our twelve-year-old client was beaten by gangs so severely that he suffered a suspected traumatic brain injury. MS-13 gang members subsequently held him in their home, closely monitored his movements, and drugged him in order to coerce him into selling drugs and extorting businesses.

We have represented minors who were forced to 'deliver or sell drugs, transport firearms, participate in extortion practices, spy on rival gangs, monitor entry points of gang territory for the entry of police and outsiders, and/or provide

\footnotetext{
1422 USC S 7102(3).

15 Boerman and Golob, p. 2.

16 D Gold, 'The Redemption of MS-13', Pulitzer Center, 20 December 2018, https:// pulitzercenter.org/stories/redemption-ms-13.
} 
them with other intelligence they deem to be of relevance'. ${ }^{17}$ Gang members might also force children to perform more serious acts such as violence against rival gangs, putting these children at risk of harm or detection by the police rather than their own members. Gangs often force young women to engage in sexual activities, enter forced relationships, or provide gender-normative labour. Although recent reports document that women and girls increasingly hold leadership roles within the gangs and perform tasks traditionally performed by men, gang culture is still characterised by extreme male domination and control over women. ${ }^{18}$

Notably, the status within the gangs of youths coerced into servitude, on the one hand, and gang members, on the other hand, is incredibly different. As opposed to 'gang membership — which entails recognition as a member and benefits such as camaraderie, power, protection, status, money, etc.', children who are made to perform labour for the gang are in a state of 'coerced servitude, which deprives targeted youths of all personal agency, rights, or authenticity [and does not] confer membership status on them or involve benefits of any type'. ${ }^{19}$ Gangs often forcibly recruit young children to perform criminal activities because children can avoid criminal prosecution. ${ }^{20}$ Gangs threaten harm to the children and their family members, and follow through on these threats, in order to coerce the children's servitude. ${ }^{21}$ Unlike gang members, who receive power, status, and money, coerced children may receive meagre benefits, such as a place to live or paltry sums of money, or no benefits at all. ${ }^{22}$

Given that our work as immigration attorneys involves representing immigrants in humanitarian applications for relief, we predominantly see youths who are fleeing Central America out of fear of the gangs. As a result, we predominantly

17 Ibid., p. 12.

18 I Aguilar Umaña and J Rikkers, Violent Women and Violence Against Women: Gender relations in the Maras and other street gangs of Central America's Northern Triangle region, Initiative for Peacebuilding and Interpeace, 2012, p. 12, retrieved 9 January 2021, https://www. interpeace.org/wp-content/uploads/2012/09/2012_09_18_IfP_EW_Women_In_ Gangs.pdf.

19 Boerman and Golob, p. 11.

20 JJ Fogelbach, 'Gangs, Violence, and Victims in El Salvador, Guatemala, and Honduras', San Diego Int'l LJ, vol. 12, issue 1, 2011, p. 432, https://digital.sandiego.edu/cgi/ viewcontent.cgi?article $=1100 \&$ context $=$ ilj.

21 Ibid.; Boerman and Golob, p. 11; P Goldberg et al., Children On the Run: Unaccompanied Children leaving Central America and Mexico and the need for international protection, UNHCR, Geneva, 2014, pp. 94-95, https://www.researchgate.net/publication/267041912_ Children_on_the_Run_Unaccompanied_Children_Leaving_Central_America_and_ Mexico_and_the_Need_for_International_Protection.

22 Fogelbach, p. 432; Boerman and Golob, p. 11. 
represent youths who were forced to join the gang or to continue working for the gang despite wanting to leave. In this article we, thus, focus on cases that arguably meet the definition of trafficking in the TVPA to demonstrate how the US is falling short of its obligations to protect trafficking victims. These youths, who were obviously forced into serving the gangs are, in our professional experience, generally viewed as criminals rather than trafficking victims in the US immigration system. For example, though we believe Samuel meets the legal definition of a labour trafficking victim, his past conduct renders him ineligible for most of the forms of immigration relief for which he otherwise qualifies.

As several empirical studies have described in various contexts around the world, legal and law enforcement narratives often present a black-and-white view of trafficking perpetrators and victims, furthering the 'perfect victim' narrative, while ethnographic accounts tend to be much more nuanced and complex. ${ }^{23}$ In the context of children trafficked for exploitation in criminal activities, competing narratives are again at play. As these children's legal representatives, we attempt to portray a nuanced picture of their lives to demonstrate the coercion and force they endured. However, US immigration authorities and law enforcement advance a much more black-and-white narrative that views all children with gang involvement as 'criminals' with little to no regard of whether the children were trafficked for criminal exploitation by the gangs or willing gang members. Part of the issue may be that children often identify themselves as 'gang members' and do not perceive themselves as victims. As their attorneys, we spend hours talking about their cases to understand the factors that led to their involvement, while US immigration and law enforcement authorities frequently do not make these inquiries.

A larger issue is the rhetoric perpetuated by the Trump Administration casting Central American minors seeking protection as 'rough, tough MS-13 gang members' and justifying its increasingly stringent immigration policies as

23 BCO Breuil et al., 'Human Trafficking Revisited: Legal, enforcement and ethnographic narratives on sex trafficking to Western Europe', Trends in Organized Crime, vol. 14, issue 1, 2011, pp. 30-45, p. 43, https://doi.org/10.1007/s12117-011-9118-0; G Sanchez, "Circuit Children": The experiences and perspectives of children engaged in migrant smuggling facilitation on the US-Mexico border', Anti-Trafficking Review, issue 11, 2018, pp. 103-119, https://doi.org/10.14197/atr.201218117; G Sanchez, "It's All in Their Brain": Constructing the figure of the trafficking victim on the USMexico border', Anti-Trafficking Review, issue 7, 2016, pp. 97-114, https://doi. org/10.14197/atr.20121776; SX Zhang, 'Woman Pullers: Pimping and sex trafficking in a Mexican border city', Crime, Law and Social Change, vol. 56, issue 5, 2011, pp. 509528, https://doi.org/10.1007/s10611-011-9333-2. 
necessary to protect US citizens from an 'invasion' of dangerous criminals. ${ }^{24}$ This rhetoric fails to consider that these children, including many of those who were in fact affiliated with gangs, are themselves victims of gang violence and in need of protection. This mistreatment of children who have been forced to engage in criminal activities is part of a larger immigration legal system that carries strict penalties for criminal behaviour, with few defences for trafficking victims.

Below, we will explore how the US immigration system denies protection to Central American minors trafficked for exploitation in criminal activities by gangs in three areas of immigration law: inadmissibility grounds, bars to asylum, and detention. Although this is not an exhaustive discussion of the US immigration system, we have chosen to focus on these areas because, based on our practice, we believe they are most relevant to this population.

\section{Inadmissibility Grounds}

A complex set of 'inadmissibility grounds' governs who is and is not eligible for admission, or lawful status, in the US. These grounds exclude individuals for a wide array of reasons, including health- and economic-related issues and past criminal and immigration violations. This section will provide a brief overview of criminal-related inadmissibility grounds and then demonstrate the harsh consequences of these grounds by providing case examples of two forms of humanitarian relief relevant to Central American minor trafficking victims: the T nonimmigrant visa ( $\mathrm{T}$ visa) and Special Immigrant Juvenile Status (SIJS).

\section{Overview of Criminal-Related Inadmissibility Grounds}

The criminal-related inadmissibility grounds are broad and exclude not only immigrants with certain criminal convictions, but also those who have admitted to certain conduct or who are suspected by the US Government of engaging in certain conduct. The most common criminal grounds of inadmissibility apply to individuals who (1) were convicted of or admit committing a crime of moral turpitude (CIMT), which is ambiguously defined as involving conduct that is 'inherently base, vile, or depraved', ${ }^{25}$ (2) were convicted of or who admit

24 D Nakamura, 'Trump Says the Border Crisis is About Criminals and Gangs. His administration says it is about families and children', The Washington Post, 1 May 2019, retrieved 30 May 2020, https://www.washingtonpost.com/politics/trump-says-theborder-crisis-is-about-criminals-and-gangs-his-administration-says-it-is-about-familiesand-children/2019/05/01/0f94d78c-6c37-11e9-8f44-e8d8bb1df986_story.html.

25 Matter of Olquin, 23 I\&N Dec. 896, 896 (BIA 2006) (citing Matter of Torres-Varela, 23 I\&N Dec. 78 (BIA 2001)). 
committing a controlled substance violation, (3) were convicted of two or more offenses and received aggregate sentences of five years or more, and (4) anyone who the Attorney General has 'reason to believe' may be a drug trafficker. ${ }^{26}$

Under the broad reach of these inadmissibility grounds, children may suffer severe immigration consequences. Juvenile delinquency adjudications are not treated as 'convictions' under immigration law, and therefore do not render an individual inadmissible for having been 'convicted' of a certain crime. ${ }^{27}$ However, even absent a conviction, children may be found inadmissible if they have admitted to engaging in certain conduct, such as theft, marijuana possession, or aggravated assault. Additionally, no conviction is required for the Attorney General to have 'reason to believe' an individual is engaged in drug trafficking, and the government can point to statements made by a child to border officials, juvenile delinquency charges, or anything else that could amount to 'sufficient evidence [which] shows such facts' that establish an immigrant's history of drug trafficking. ${ }^{28}$

Waivers are available for certain grounds of inadmissibility depending on the form of relief, but even then, an application can still be denied based on negative discretionary factors such as criminal history. Below, we provide examples of two common forms of relief for this population, the T visa and SIJS, to show how the US Government routinely denies protection to minors trafficked for exploitation in criminal activities by gangs.

\section{Tvisa}

The $\mathrm{T}$ visa was created by the US Congress in 2000 with the enactment of the TVPA to provide immigration relief to victims of human trafficking. The $\mathrm{T}$ visa is the only form of immigration relief that provides an explicit waiver of inadmissibility grounds that result from human trafficking, ${ }^{29}$ reflecting Congress's goal to not hold victims of trafficking accountable for crimes they were forced to commit.

However, this waiver is not available to many Central American minors trafficked by gangs. With limited exceptions, individuals who were solely subjected to trafficking outside the US are not eligible for a $\mathrm{T}$ visa. Therefore, Central American minors who were subjected to forced labour in their home countries, but not in the US, are generally not eligible for this humanitarian

\footnotetext{
26 The statute specifying the inadmissibility grounds is 8 USC $\$ 1182(a)$.

27 Matter of Devison, 22 I\&N Dec. 1362 (BIA 2000) (en banc), citing Matter of C.M., 5 I\&N Dec. 27 (BIA 1953), Matter of Ramirez-Rivero, 18 I\&N Dec. 135 (BIA 1981).

28 Castano v. INS, 956 F.2d 236, 238 (11th Cir. 1992).

298 U.S.C. $\$ 1182(\mathrm{~d})(13)$.
} 
visa and therefore cannot waive any criminal inadmissibility grounds under this waiver.

Additionally, in practice, the agency that adjudicates the applications for $\mathrm{T}$ visas, US Citizenship and Immigration Services (USCIS), increasingly scrutinises and denies applications for $T$ visas and waivers for criminal activity, even when the criminal activity resulted from trafficking. ${ }^{30}$ Increasing rates of denials, coupled with the Trump Administration's 2018 policy to initiate removal proceedings against applicants whose cases were denied, has severely harmed many victims of trafficking and dissuaded many others from seeking protection, particularly victims with criminal histories. ${ }^{31}$

For example, one of our cases involved Hector, a Honduran minor who applied for a $\mathrm{T}$ visa after being subjected to forced labour by MS-13 in both Honduras and the US. USCIS issued two Requests for Evidence (RFEs) questioning whether Hector deserved a waiver of the inadmissibility grounds resulting from the forced criminal activity. USCIS did not address Hector's young age at the time of the forced labour and emphasised that the severity of his past criminal history could lead to a denial, even though it was forced. Thus, Hector was placed in the absurd situation where the forced labour giving rise to his eligibility for the $T$ visa could also render him ineligible for protection. Although Hector's T visa was eventually approved, his application was pending for several years due to USCIS's repeated RFEs. During this time, he lived in fear of being deported and harmed by the gang from which he sought protection, and he was unable to work legally or receive public benefits to recover from his exploitation.

Given the increased denials and scrutiny of $\mathrm{T}$ visa applications under the Trump Administration, it is apparent that trafficking victims with forced criminal histories are not receiving protections, even when a waiver is available. Therefore, not only are waivers necessary, but they also need to be adjudicated in a manner consistent with the goals of the TVPA. Below, we will see the disproportionate consequences for trafficking victims who are minors when waivers are not available.

\section{Special Immigrant Juvenile Status (SIIS)}

SIJS provides a path to status for immigrant minors, defined as under 21 years of age, for whom a juvenile court has found that reunification with one or both

30 J Krajeski, 'The Hypocrisy of Trump's Anti-Trafficking Argument for a Border Wall', The Atlantic, 5 February 2019, https://www.newyorker.com/news/news-desk/thehypocrisy-of-trumps-anti-trafficking-argument-for-a-border-wall.

31 Ibid.; K Finley, Access to Justice in a Climate of Fear: New burdles and barriers for survivors of buman trafficking and domestic violence, Center for Migration Studies, 29 January 2019, https://cmsny.org/publications/finley-climate-of-fear. 
parents is not viable due to abuse, abandonment, neglect, or a similar basis under the law, and that it is not in their best interest to return to their country of origin or last habitual residence. SIJS applicants are subject to many of the inadmissibility grounds, including those based on criminal activity, with few or no waivers available.

Most notably for children who have been trafficked by gang members, there is no waiver available for SIJS recipients if immigration authorities have 'reason to believe' that the child has trafficked drugs or assisted a drug trafficker in trafficking activities. ${ }^{32}$ As discussed above, for a child to be inadmissible under this ground, they need not have been convicted, and USCIS in practice does not consider duress or capacity in making this finding. For example, our client Jorge was forced by his father, a member of MS-13, to transport drugs at the age of 14. He was granted SIJS based on his father's neglect and abuse. However, Jorge's application for Lawful Permanent Residence pursuant to SIJS was denied on the basis that there was 'reason to believe' he was a drug trafficker, rendering him inadmissible. This finding was based solely on his statements to law enforcement at the border and a subsequent sworn statement about his father's mistreatment.

Effectively, Jorge's application was denied based on the same facts which formed the basis for his eligibility for humanitarian protection - the victimisation by his father. He was not afforded the protection that was contemplated in the enactment of SIJS as a form of relief for vulnerable children. Despite arguing that he should be afforded defences based on duress and infancy, and that a denial frustrated Congress's intent behind SIJS, the officer adjudicating his case stuck to the hardline rule that there was sufficient 'reason to believe' he was a drug trafficker. As such, explicit waivers for duress and infancy should be implemented to allow children like Jorge to receive protection.

\section{Bars to Asylum}

Many articles have discussed how the US asylum system has failed to protect Central Americans fleeing gang violence. ${ }^{33}$ In order to qualify for asylum, an applicant must establish that 'race, religion, nationality, membership in a particular social group, or political opinion was or will be at least one central reason for persecuting the applicant'. ${ }^{34}$ Scholars and practitioners have focused

\footnotetext{
328 U.S.C. $\int 1182(\mathrm{a})(2)(\mathrm{C})$.

33 See, for example: LM Harris and MM Weibel, 'Matter of S-E-G-: The final nail in the coffin for gang-related asylum claims’, Berkeley La Raza Law Journal, vol. 20, issue 1, 2010, pp. 5-30, http://doi.org/10.15779/Z38S36K.

348 U.S.C. $\int 1158(\mathrm{~b})(1)(\mathrm{B})$.
} 
primarily on the interpretation of 'particular social group' (PSG), a category that courts have generally interpreted as excluding many groups related to gang violence or recruitment. ${ }^{35}$ However, there has been little written on the harsh application of these bars to Central American asylum seekers, particularly minors who were trafficked for criminal activity by gangs. Below, we will discuss two of the bars most relevant to these minors: the serious nonpolitical crime bar and the persecutor bar.

\section{Serious Nonpolitical Crime Bar}

Asylum seekers can be barred from receiving asylum if 'there are serious reasons to believe the alien has committed a serious nonpolitical crime' outside of the US, ${ }^{36}$ a category that includes robbery, ${ }^{37}$ drug trafficking, ${ }^{38}$ and assault. ${ }^{39}$ Even though the Board of Immigration Appeals (BIA), an appellate body that reviews the decisions of immigration judges, has repeatedly stated that 'juvenile delinquency proceedings are not criminal proceedings', several courts have found that juvenile criminal conduct can be considered a serious nonpolitical crime for the purposes of asylum. ${ }^{40}$

Although some courts have appeared to read a duress defence into this bar, they have generally declined to find that asylum seekers' behaviour was under duress, even in the face of extremely coercive situations involving minors. For example, the case Urbina-Mejia $v$. Holder involved a Honduran asylum seeker who was forced to join the 18th Street gang when he was 14 years old. He testified that gang members " "persuaded" him to join by continuously beating him for eighteen seconds', a common initiation practice. He was threatened with death if he did not comply with the gang's demands and was forced to extort and beat the gang's victims. Discounting the coercion experienced by Urbina-Mejia and his young age when he was forced to join the gang, the court found that he was barred from relief for having committed a 'serious nonpolitical crime'. ${ }^{41}$

\section{Persecutor Bar}

Under what is referred to as the persecutor bar, applicants are barred from asylum if they have 'ordered, incited, assisted, or otherwise participated in the

\footnotetext{
35 Matter of S-E-G-, 24 I\&N Dec. 579 (BIA 2008).

368 USC $\int 1158(\mathrm{~b})(2)(\mathrm{A})(\mathrm{iii})$.

37 Matter of Ballester-Garcia, 17 I\&N 592 (BIA 1980).

38 Go v. Holder, 640 F.3d 1047 (9th Cir. 2011).

39 Zheng v. Holder, 698 F.3d 710 (8th Cir. 2013).

40 Matter of Devison, 22 I. \& N. Dec. 1362, 1365 (BIA 2001).

41 Urbina-Mejia v. Holder, 597 F.3d 360 (6th Cit. 2010).
} 
persecution of any person on account of race, religion, nationality, membership in a particular social group, or political opinion'. ${ }^{42}$ The persecutor bar contains no explicit infancy or duress exceptions, and several articles have focused on the unjust application of the persecutor bar to child soldiers. As one commentator argued, 'Barring child soldiers from asylum protection penalizes them for having been the victims of a crime and undercuts all of the United States' efforts to protect them. ${ }^{43}$ Many Central American minors escaping gang violence may find themselves in a similar situation when facing the US immigration system: rather than receiving protection, they are treated as persecutors.

For several decades, courts declined to read an implicit duress defence into the persecutor bar, even in the case of children. One of the few circuit cases involving the applicability of the persecutor bar to children involved Amadu Bah, who as a child was forced to join the Revolutionary United Front (RUF), an insurgent group in Sierra Leone. In Bab v. Ashcroft, the Fifth Circuit declined to read an implicit duress or infancy exception into the persecutor bar and found that Bah was barred from receiving asylum. ${ }^{44}$

In a short-lived victory, the BIA enunciated a duress defence in 2018 in the case Matter of Negusie. However, just six months after this decision, Attorney General Sessions certified the case to himself for review, a process frequently used by the Trump Administration that allows the Attorney General to overrule decisions by the BIA. ${ }^{45}$ In November 2020, the Attorney General issued his decision in Matter of Negusie holding that ' $[\mathrm{t}]$ he bar to eligibility for asylum and withholding of removal based on the persecution of others does not include an exception for coercion or duress' and that the applicant for asylum, rather than the government, bears the burden to show they are not subject to this bar. ${ }^{46}$ As demonstrated, the broad reach of these bars precludes many minors trafficked for exploitation in criminal activities by gangs from receiving humanitarian protection, with little to no consideration of whether the minor had the mental capacity to understand the nature of their actions and whether the activity was forced. In order to avoid the harsh consequences of these bars, adjudicators need to incorporate principles of infancy and duress into their determinations.

\footnotetext{
428 USC $\int 1158(\mathrm{~b})(2)(\mathrm{A})(\mathrm{i})$.

43 B Lonegan, 'Sinners or Saints: Child soldiers and the persecutor bar to asylum after Negusie v. Holder', BC Third World LJ, vol. 31, issue 1, 2011, pp. 71-99, p. 72, https:// lawdigitalcommons.bc.edu $/ \mathrm{cgi} /$ viewcontent.cgi?article $=1003 \&$ context $=$ twlj.

$44 \quad 341$ F.3d 348 (2003).

4527 I\&N Dec. 481 (A.G. 2018).

46 Matter of Neguise, 28 I\&N Dec. 120 (A.G. 2020).
} 


\section{Detention}

\section{Detention of Immigrant Children}

Central American minors who have been trafficked for criminal activity by gangs are often subject to prolonged detention by the US government in jail-like settings as a result of their victimisation. The US has largely ignored widely agreed upon tenets of international law with the practice of detaining immigrant children based on their immigration status or that of their parents. The Convention on the Rights of the Child, to which the US is not a signatory, states that children should be detained only as a last resort, and the UN Committee on the Rights of the Child has stated that member states 'should expeditiously and completely cease the detention of children on the basis of their immigration status'. ${ }^{47}$

Since 2003, unaccompanied immigrant children who are apprehended by the US Department of Homeland Security (DHS) either upon entry to the US or in the interior of the country are detained in the custody of the US Department of Health and Human Services, Office of Refugee Resettlement (ORR). Detentions have increased dramatically in recent years following the surge of unaccompanied minors from Central America seeking protection in 2014. In fiscal year 2019, DHS referred 69,488 children to ORR. Children remained with ORR for an average of 66 days. Central Americans made up the majority of those children, with 30 per cent from Honduras, 45 per cent from Guatemala, and 18 per cent from El Salvador. ${ }^{48}$

The Flores Settlement Agreement, which established national standards for the detention and treatment of children in federal custody, and the Trafficking Victims Protection Reauthorization Act task ORR with holding children in the least restrictive setting' and ultimately releasing them to sponsors, including parents, relatives, or other individuals. ${ }^{49}$ In making this determination, ORR considers

47 UN Committee on the Rights of the Child, Committee on the Rights of the Child, Report of the 2012 Day of General Discussion on the Rights of All Cbildren in the Context of International Migration, 28 September 2012, paragraph 78, https://www.refworld.org/ docid/51efb6fa4.html.

48 Office of Refugee Resettlement, 'Unaccompanied Children: Facts and data', retrieved 31 May 2020, https://www.acf.hhs.gov/orr/about/ucs/facts-and-data.

49 Stipulated Settlement Agreement, Flores v. Reno, No. CV 85-4544-RJK (Px) (C.D. Cal. Jan. 17, 1997); 8 U.S.C. \ 1232 (TVPRA). 
what danger a child poses to the community. ${ }^{50}$ Troublingly, practitioners report that ORR has used a child's status as a victim of trafficking by gangs as a basis for finding that a child poses danger. On this basis, ORR can detain children in high-security facilities and prolong release processes, meaning a child must remain in a restrictive detention facility longer rather than being released to family.

Similarly, unsubstantiated allegations of gang affiliation have led to the prolonged detention of minors in secure facilities. For example, in 2018, multiple federal and New York state law enforcement agencies launched 'Operation Matador', a law enforcement effort with the goal of 'identifying, interdicting and investigating a wide variety of transnational border crime with a concentration on MS-13 gang activity'. ${ }^{51}$ Federal law enforcement agencies touted as a success the arrest of ninety-nine individuals who entered the US as unaccompanied minors, sixty-four of whom had received SIJS status. As many as twelve of those arrested, who were still minors at the time of their arrest, were then subjected to detention by ORR. ${ }^{52}$

A lawsuit filed by the American Civil Liberties Union (ACLU) in the aftermath of Operation Matador described the arrests and subsequent detentions as having been 'based on flimsy, unreliable and unsubstantiated allegations of gang affiliation', including wearing a Salvadoran soccer jersey. ${ }^{53}$ The ACLU also alleged that ' $[t]$ he agencies in charge of this effort do not undertake any meaningful review of the allegations of gang affiliation on which their decisions are based; do not inform the children, their families or their immigration counsel of the basis of these allegations; and do not provide them any opportunity to review or challenge the evidence upon which the government relies to place the children in jail-like conditions, destroy family integrity, and deny or interfere with access to relief under U.S. immigration laws' ${ }^{54}$

50 ORR indicates that a child's behaviour, criminal or juvenile background (including if a child 'has been charged with or convicted of a criminal offense, or is chargeable with such an offense'), danger to self, and danger to the community are all factors relevant to making a placement decision. Office of Refugee Resettlement, 'Children Entering the United States Unaccompanied: Section 1', 30 January 2015, https:// www.acf.hhs.gov/orr/resource/children-entering-the-united-states-unaccompaniedsection-1.

51 US Immigration and Customs Enforcement, 'Joint Operation Nets 24 Transnational Gang Members, 475 Total Arrests Under Operation Matador', 29 March 2018, retrieved 31 May 2020, https://www.ice.gov/news/releases/joint-operation-nets-24transnational-gang-members-475-total-arrests-under-operation.

52

Ibid.

Gomez v. Sessions, Case No. 3:17-cv-03615-VC (N.D. Cal. 2017) (amended complaint Ф甲 1,97).

Ibid. $\uparrow 2$. 
For example, Junior, a minor who resisted gang recruitment in both Honduras and the US, was detained in a secure ORR facility following allegations he was an MS-13 gang member based on unsubstantiated claims that he had drawings of MS-13 in his schoolwork and was seen with gang members. ${ }^{55}$ The psychological effects on children of detention are severe: Junior attempted suicide and described the detention facility as 'a living hell'. ${ }^{56}$ Junior's story epitomises the devastating consequences on Central American minors of an immigration system focused overwhelmingly on criminal enforcement tactics and the demonisation of immigrant youths as gang members, instead of on humanitarian protections.

\section{Adult Detention Based on Criminal Activities as Minors}

Additionally, adults may also be detained based on allegations of gang activity and crimes committed when they were minors, with no meaningful inquiry into whether the activities were performed under duress and no exception based on infancy. Immigration judges have broad discretion in deciding whether an individual should be released on bond. The judge's first inquiry is whether or not an immigrant poses a danger to the community, before considering flight risk or other factors. ${ }^{57}$ As a result, many bond hearings are overwhelmingly focused on the presumed danger an immigrant may pose to society.

Although gang membership is not a crime, government attorneys from DHS, the agency tasked with prosecuting immigration cases, increasingly use allegations of gang membership to argue that an immigrant poses a danger to society and should therefore not be released from detention. Because of the lack of rigorous evidentiary standards in US immigration courts, government attorneys from DHS often submit feeble evidence and make uncorroborated claims to oppose release of immigrants from detention. These claims are often contained only in DHS's own documents and rely on hackneyed facts such as immigrants' clothes, associations, tattoos, or grooming. Government attorneys often also submit police reports, even when such reports did not result in arrests, charges, or convictions. ${ }^{58}$ As an ICE officer explained, 'The purpose of classifying him as a gang member or a gang associate is because once he goes in front of an immigration judge, we

55 A Tsui, 'In Crackdown on MS-13, a New Detention Policy Raises Alarms', PBS: Frontline, 18 February 2018, https://www.pbs.org/wgbh/frontline/article/incrackdown-on-ms-13-a-new-detention-policy-raises-alarms.

Ibid.

57 In re Urena, 25 I\&N Dec. 140, 141 (BIA 2009).

58 L Hlass, 'The School to Deportation Pipeline', Ga. St. UL Rev., vol. 34, issue 3, Spring 2018, pp. 697-763, https://readingroom.law.gsu.edu/cgi/viewcontent. cgiparticle $=2931 \&$ context $=$ gsulr. 
don't want him to get bail'. ${ }^{59}$

Furthermore, immigration judges regularly rely on these unsubstantiated claims of government attorneys to find a respondent a danger to the public and as such not meriting release. As in the other contexts described above, there is no requirement that the judge consider duress or minority when reviewing such findings. For example, one of our clients was held in immigration detention as an adult and denied bond based on an allegation that he was a gang member-an unsubstantiated allegation that arose in a delinquency adjudication from when he was only nine years old.

Another client, who was detained shortly after turning 18 years old, was denied bond based on activities which occurred when he was 14 years old. Having been held as a slave by gang members from the age of twelve to fourteen, he had fled his home country after his family had to purchase his freedom. Upon arriving in the US, gang members in his home country ordered gang members in the US to continue to pursue him, resulting in altercations at his high school. The court relied upon these altercations, of which there was limited probative evidence, and which did not result in any arrest or criminal charges, to deny bond. The result was that the same individual continued to be held in detention and was brutally attacked by members of the same gang in the detention facility. Essentially, the US government's mischaracterisation of his victimhood as connoting his membership in a gang caused him to be further harmed by that same gang.

\section{Conclusion}

This article seeks to contribute to the literature on the harmful effects of the US immigration system by focusing on its particularly severe and disproportionate consequences for Central American minors trafficked for exploitation in criminal activities by gangs. This system, which is based on the 'demonization of migrants and discussions of migration as a threatening unknown', ${ }^{60}$ is in direct conflict with the humanitarian ideals the US claims to value. Despite the US government's obligations under the Refugee Convention and the TVPA, the US immigration system routinely denies protection to child trafficking victims. Rather than receiving protection, children who are trafficked for exploitation in criminal activities are frequently held accountable in the US immigration system for the crimes they were forced to commit, a practice that is urgently disadvised by both the TVPA and international treaties.

59 'Inside ICE's Controversial Crackdown on MS-13', CBS This Morning, 16 November 2017, https://www.cbsnews.com/news/ms-13-gang-ice-crackdown-thomas-homan.

60 CC García Hernández, 'Deconstructing Crimmigration', University of California Davis Law Review, vol. 52, 2019, pp. 197-253, p. 214. 
An important step in moving toward an immigration system that protects human trafficking victims is incorporating principles regarding the capacity of minors and the culpability of trafficking victims-principles that have been widely accepted and adopted in other areas of law in the US and around the world. The incorporation of infancy and duress exceptions into US immigration legislation and adjudication processes would help ensure that minors trafficked for exploitation in criminal activities receive the humanitarian protection they need.

The views expressed in this article are those of the authors and do not necessarily reflect the official position of their employer.

Katherine Soltis is a Supervising Immigration Attorney at Ayuda, a non-profit organisation that advocates for low-income immigrants through legal, social, and language access services in the Washington, DC metropolitan region. She graduated cum laude from Harvard Law School and obtained her bachelor's degree from Duke University. She represents both child and adult survivors of trafficking in a variety of matters before USCIS, the Arlington Immigration Court, and Virginia Juvenile and Domestic Relations District Courts. Email: katie.soltis@ayuda.com

Madeline Taylor Diaz is a Supervising Immigration Attorney at Ayuda and a programme manager of Ayuda's Detained Children Program. She graduated from the Catholic University of America, Columbus School of Law and obtained her bachelor's degree from George Washington University where she studied Latin American Studies. She has focused her practice on representing immigrant children before USCIS, the Arlington Immigration Court, and the Virginia state courts. Email: madeline.taylordiaz@ayuda.com 